\title{
$B s m /$ gene polymorphism of vitamin D receptor in obese Egyptian male medical students and its relationship with vitamin D deficiency
}

Yara Khattab ${ }^{{ }^{*} \mathbb{D}}$, Randa Reda ${ }^{1}$, Maha El-Gaafary², Yasser Zeitoun ${ }^{1}$, Rania Abo-Shady ${ }^{1}$ and Walid Abdelhady ${ }^{1}$

\begin{abstract}
Background: Vitamin D regulates cell proliferation and differentiation and exhibits immunoregulatory, antiangiogenic, and antioxidant characteristics. Vitamin D deficiency and vitamin D receptor (VDR) gene polymorphisms have been associated with an increased risk of metabolic syndrome components such as abdominal obesity, with both vitamin D deficiency and VDR gene polymorphisms contributing to its development. Obesity, metabolic disorders, and bone mass defects are associated with VDR alleles. The importance of VDR in the etiology of obesity has been related to the existence of the VDR polymorphisms Fokl, Bsml, Apal, and Taql. VDR expression in adipocytes affects energy metabolism and aids in obesity development.
\end{abstract}

Objective: The aim of this study was to examine a possible association between $B s m l$ ( $B, b$ allele) polymorphism in the VDR gene and vitamin D status in obese Egyptian male medical students.

Patients and methods: This study was based on a comprehensive experiment known as "Nutritional Assessment of Medical Educational Students (NAMES)"that was completed in 2018 with 700 healthy participants (men and women). In total, out of the 700 participants 30 healthy men were enrolled in this study who matched our inclusion criteria. They attended Ain Shams University Hospital in Cairo between April 2019 and November 2020. This study was conducted at the Clinical Pathology Department of Ain Shams University Hospital, which is a part of the Faculty of Medicine. Participants were divided into two groups: Group I consisted of 12 obese men with nondeficient vitamin D levels (> $20 \mathrm{ng} / \mathrm{dl}$ ), and Group II consisted of 18 obese men with deficient vitamin D levels ( $20 \mathrm{ng} / \mathrm{dl})$. Peripheral blood samples were collected into EDTA tubes from all groups, and DNA was extracted and purified using spin purification for PCR (QIA amp DNA Mini Kit). A commercial real-time polymerase chain reaction (PCR) kit with predesigned TaqMan probes was used to analyze the single nucleotide polymorphism (SNP) (Bsm/) rs 1544410 in the VDR gene.

Results: No statistically significant relationship was observed between vitamin D levels and all InBody bioelectrical impedance characteristics, as well as Bsm/ gene polymorphism and all InBody bioelectrical impedance parameters $(P>0.05)$. Regarding $B b$ and $B B$ genotypes, no statistically significant difference was observed between Groups I and II. The prevalence of $B B$ genotype was higher in vitamin-D-deficient individuals, and $B b$ genotype was more common among obese participants than BB genotype, which showed a higher prevalence of the " $b$ " gene; however, these

\footnotetext{
*Correspondence: khattab_yara@yahoo.com

1 Department of Clinical Pathology, Faculty of Medicine, Ain Shams

University, Ramses Street (Ahmed Lotfy Elsayed Street), Abbassia,

Cairo 11566, Egypt

Full list of author information is available at the end of the article
} 
were not significant. Iron profile (iron level, ferritin level, $\mathrm{TIBC}$, and transferrin saturation) and Bsm/ gene polymorphism showed no statistically significant relationship ( $P>0.05$ ). Glycated hemoglobin ( $\mathrm{HbA1C}$ ) level and Bsm/ gene polymorphism showed a statistically significant relationship $(P=0.002)$, with a higher mean value among $B b$ genotype carriers than among $B B$ genotype carriers. Eosinophil count showed a statistically significant difference between $B B$ and $B b$ genotype carriers $(P=0.045)$, with a higher mean value among $B b$ genotype carriers than among $B B$ genotype car-

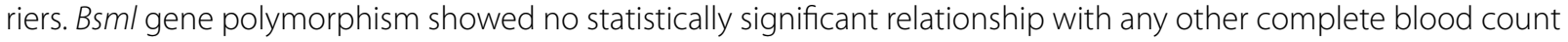
parameters $(P>0.05$.

Conclusion: There was no significant relationship between VDR gene polymorphism (Bsml) and body mass index (BMI) nor between the different InBody bioelectrical impedance parameters. We noticed the prevalence of $B B$ genotype among vitamin-D-deficient obese students and the frequency of the " $b$ " allele among obese candidates according to the findings of our study. There was also no significant relationship between Bsm/ gene polymorphism and vitamin D levels. However, Bsm/ gene polymorphism and HbA1c levels and eosinophil count showed a relationship, which requires further investigation.

Keywords: Vitamin D deficiency, Bsml gene polymorphism, VDR gene polymorphism, Obesity

\section{Background}

The vitamin $\mathrm{D}$ endocrine system takes part in various biological processes including musculoskeletal development, erythropoiesis, and blood pressure regulation. Yet, it was estimated that one billion people had deficient or insufficient levels of vitamin D based on population studies [1].

Factors that have been associated with increased risk of vitamin D deficiency include low skin exposure to sunlight, low dietary intake of vitamin $\mathrm{D}$, high body mass index (BMI), and genetic predispositions [2].

Several hypotheses were proposed to correlate obesity with vitamin D deficiency. There was evidence that vitamin D storage, action, and metabolism influences adiposity, and an observational study had shown that there is an increased risk of deficiency among obese individuals, but detailed explained causes are not clear. The hormonal form of vitamin $\mathrm{D}$ is (1,25 dihydroxyvitamin $\mathrm{D})$ hormone, which has many other activities such as the regulation of adipocytes [3].

Vitamin D deficiency has also been linked to an increased risk of metabolic syndrome components including abdominal obesity [4]. VDR is a gene that encodes a nuclear receptor to mediate the inhibitory impact of vitamin D3 on adipogenesis [5]. The VDR gene plays a crucial role in the modulation of vitamin $D$ pathways and regulation of hormone responsive genes. Interestingly, the VDR gene is also expressed in adipocytes and pancreatic beta cells and thus may influence body composition by directly regulating the differentiation and metabolism of adipocytes, or indirectly by insulin modulation [6]. The relevance of VDR in the etiology of obesity has been connected to the existence of polymorphisms FokI, BsmI, ApaI, and TaqI [7]. SNPs that cause the lower expression of VDR mRNA and protein such as BsmI may be associated with an increase the liability to obesity
[5]. The BsmI polymorphism (rs1544410), located in the intronic region (intron 8 near the $3^{\prime}$ end), is thought to affect VDR translational activity due to its strong linkage disequilibrium with a polyadenosine (poly (A)) microsatellite repeat in the $3^{\prime}$ untranslated region [8]. Studies as the study of Al-Hazmi et al. demonstrated that polymorphisms in BsmI loci of the VDR gene were closely associated with the susceptibility of obesity [9].

The present study was conducted to examine a possible correlation between BsmI polymorphism and vitamin D levels in obese Egyptian male medical students.

\section{Methods}

This study was based on a comprehensive investigation known as Nutritional Assessment of Medical Educational Students (NAMES) that was conducted in 2018 and involved 700 healthy subjects (men and women). A total of 30 healthy men were enrolled in this study of the 700 participants who matched our inclusion criteria. These patients attended Ain Shams University Hospital in Cairo. The research was carried out at Clinical Pathology Department, Ain Shams University Hospitals.

The participants were divided into two groups. Group I included 12 obese men with a vitamin D level of $>20 \mathrm{ng} /$ $\mathrm{dl}$ who were subdivided into seven men with insufficient vitamin D levels $(21-29 \mathrm{ng} / \mathrm{ml})$ and five men with normal vitamin D levels ( $>30 \mathrm{ng} / \mathrm{ml}$ ). Group II included 18 obese men with vitamin $\mathrm{D}$ deficiency $(<20 \mathrm{ng} / \mathrm{dl})$.

Inclusion criteria were age between 18 and 25 years, male gender, and a BMI of $>30 \mathrm{~kg} / \mathrm{m}^{2}$. The exclusion criterion was a history of chronic medical illness.

All the study participants underwent (1) a detailed medical history, focusing on dietary habits and drug usage, as well as a family history of obesity; (2) anthropometric measurements such as weight in kilograms, height in meters, and BMI $\left(\mathrm{kg} / \mathrm{m}^{2}\right)$; (3) clinical evaluation, 
including blood pressure monitoring and bioelectrical impedance in the body; and (4) tests for glycated hemoglobin (HbA1c) levels, complete blood count $(\mathrm{CBC})$, iron profile, vitamin D levels, and VDR (BsmI) gene polymorphisms identified using real-time PCR.

Specimen collection: From each subject, $6 \mathrm{ml}$ of venous blood was collected into sterile EDTA-containing tubes under aseptic conditions. The tubes were frozen at $-20{ }^{\circ} \mathrm{C}$ until performing PCR for detecting VDR (BsmI) gene polymorphisms.

VDR gene polymorphism (BsmI) analysis: VDR SNP $(B s m I)$ rs 1544410 analysis was conducted using a commercial real-time PCR kit with predesigned TaqMan probes (Applied Biosystems TaqMan Assay cat. no. 4351379, USA). DNA extraction was performed using a commercial real-time PCR kit with predesigned TaqMan probes (Applied Biosystems TaqMan Assay cat. no. 4351379, USA) (QIA amp DNA Blood Mini Kit, USA).

DNA purification was done using a spin technique (QIA amp NA Mini Kit). The entire process was completed in $<20 \mathrm{~min}$. The easy QIA amp spin processes yield pure DNA that can be readily used for direct amplification, making it ideal for the simultaneous processing of several samples. Both frozen whole blood and EDTA-treated blood can be used in the QIA amp technique (QIA amp DNA Mini Kit (50) Cat. No. 51304). The entire procedure was performed as per manufacturer instructions.

Standard preparation: TaqMan genotyping assays are designed and calibrated to function with TaqMan Genotyping Master Mix under the same universal thermal cycling settings. Only the following are required: 1) Each plate well contains $10 \mathrm{ng}$ of pure genomic DNA, 2) Master Mix for TaqMan genotyping, and 3) assay for SNP genotyping (specific for polymorphism).

Universal PCR Master Mix contains DNA polymerase, dNTPs, primers, and probes rs 1544410 from Thermo Fisher Scientific and uses the same thermal conditions and optimal mix components. These assays were acquired from Thermo Fisher Scientific and used on a real-time PCR Rotor-Gene Q thermocycler.

This SNP BsmI was genotyped using a VIC ${ }^{\circledR}$ labeled probe for detecting the $\mathrm{C}$ allele and a $\mathrm{FAM}^{\circledR}$ labeled probe for detecting the $\mathrm{T}$ allele. To prepare the final reaction volume of $20 \mu \mathrm{l}, 10 \mu \mathrm{l}$ TaqMan ${ }^{\circledR}$ Genotyping Master Mix, $1 \mu \mathrm{l} \mathrm{TaqMan}{ }^{\circledR}$ SNP genotyping assay (TaqMan probes), $7 \mu \mathrm{l}$ DNase-free water, and $2 \mu \mathrm{l}$ DNA were used.

TaqMan MGB probes: TaqMan ${ }^{\circledR}$ MGB probes are oligonucleotides that are unique to a certain target, i.e., rs 1544410 VIC/FAM: (GAGCAGAGCCTGAGTATTGGG AATG [C/T] GCAGGCCTGTCTGTGGCCCCAGGA A). Each probe has a reporter dye at the $5^{\prime}$ end - the $\mathrm{VIC}^{\circledR}$ dye is attached to the $5^{\prime}$ end (B) of allele $\mathrm{C}$ probe-the
$\mathrm{FAM}^{\circledR}$ dye is attached to the $5^{\prime}$ end (b) allele $\mathrm{T}$ probe. At the $3^{\prime}$ end of the probe, a nonfluorescent quencher (NFQ) is attached.

The conditions for real-time PCR were as follows: denaturation at $95^{\circ} \mathrm{C}$ for $10 \mathrm{~min}$, followed by 40 cycles of $96{ }^{\circ} \mathrm{C}$ for $15 \mathrm{~s}$ (denaturation) and $60^{\circ} \mathrm{C}$ for $1 \mathrm{~min}$ (annealing/extension). Samples were run in duplicate for 45 cycles. All ingredients were used in the TaqMan ${ }^{\circledR}$ SNP genotyping assay (ABI) (www.appliedbiosystems.com).

In any TaqMan genotyping experiment, the real-time QIAGEN Rotor-Q-gene system was used for PCR amplification and plate read analysis.

\section{Statistical methods}

Data were analyzed using the SPSS (version 23) statistical software package from the USA, which was installed on an IBM compatible PC running Windows 10.

Descriptive statistics were used to describe qualitative data in the form of numbers and percentages. For parametric data, quantitative data were described in terms of mean and standard deviation (SD).

Analytical statistics were used to compare quantitative data using Student's $t$ test. A P value of $>0.05$ indicated nonsignificant, $\mathrm{P}=0.05$ indicated significant, $\mathrm{P}=0.01$ indicated highly significant, and $\mathrm{P}=0.001$ represented highly significant.

\section{Results}

The mean \pm SD BMI of the study participants was $33.1 \pm 3.9 \mathrm{~kg} / \mathrm{m}^{2}$ (range 29.9-45.9 $\mathrm{kg} / \mathrm{m}^{2}$ ), and the mean \pm SD waist-hip ratio (WHR) was $0.90 \pm 0.07$ (range 0.77-1.10) (Table 1).

All the InBody bioelectrical impedance test parameters showed no statistically significant relationship with vitamin D levels $(\mathrm{P}>0.05)$ (Table 2).

Bsml gene polymorphism also showed no statistically significant relationship with the InBody bioelectrical impedance parameters $(\mathrm{P}>0.05)$ (Table 3$)$.

The relationship between vitamin $\mathrm{D}$ levels and the genotypes $B B$ and $B b$ of $B s m l$ gene polymorphism is presented in Table 4 and Figs. 1 and 2. There was no

Table 1 Anthropometric measures of obese male students

\begin{tabular}{lcl}
\hline Measures & Mean \pm SD & Min-Max \\
\hline Weight $(\mathrm{kg})$ & $99.3 \pm 14.2$ & $77.7-144.0$ \\
Height $\left(\mathrm{m}^{2}\right)$ & $1.73 \pm 0.06$ & $1.59-1.83$ \\
BMI $\left(\mathrm{kg} / \mathrm{m}^{2}\right)$ & $33.1 \pm 3.9$ & $29.9-45.9$ \\
Waist $(\mathrm{cm})$ & $102.7 \pm 8.6$ & $85.0-129.0$ \\
Hip $(\mathrm{cm})$ & $113.7 \pm 10.1$ & $92.0-145.0$ \\
Waist-hip ratio $($ WHR) & $0.90 \pm 0.07$ & $0.77-1.10$ \\
\hline
\end{tabular}


Table 2 Vitamin D status in relation to InBody bioelectrical impedance among obese male medical student

\begin{tabular}{llllll}
\hline & Vitamin D groups & N & Mean & SD & P value \\
\hline Total body water (L) & Group I & 12 & 46.89 & 4.95 & 0.717 NS \\
& Group II & 15 & 46.08 & 6.18 & \\
Protein (kg) & Group I & 12 & 12.72 & 1.33 & 0.685 NS \\
& Group II & 15 & 12.48 & 1.68 & \\
Minerals (kg) & Group I & 12 & 4.44 & 0.54 & 0.581 NS \\
& Group II & 15 & 4.32 & 0.55 & \\
Body fat mass (kg) & Group I & 12 & 35.15 & 4.48 & 0.410 NS \\
& Group II & 15 & 38.52 & 13.27 & \\
Percent body fat (\%) & Group I & 12 & 35.42 & 2.60 & 0.362 NS \\
& Group II & 15 & 37.36 & 6.84 & \\
Skeletal muscle mass & Group I & 12 & 36.358 & 3.99 & 0.685 NS \\
(kg) & Group II & 15 & 35.620 & 5.08 & \\
Trunk free fat mass & Group I & 12 & 28.400 & 2.76 & 0.926 NS \\
(kg) & Group II & 15 & 28.280 & 3.70 & \\
Visceral fat level & Group I & 12 & 15.08 & 2.42 & 0.449 NS \\
& Group II & 15 & 16.27 & 5.28 & \\
\hline
\end{tabular}

Table 3 Bsml Polymorphism in relation to InBody bioelectrical impedance among obese male medical students

\begin{tabular}{|c|c|c|c|c|c|}
\hline & $\begin{array}{l}\text { Bsml } \\
\text { polymorphism }\end{array}$ & $\mathrm{N}$ & Mean & SD & $P$ value \\
\hline \multirow[t]{2}{*}{ Total body water $(\mathrm{L})$} & $\mathrm{Bb}$ & 21 & 46.97 & 5.41 & $0.369 \mathrm{NS}$ \\
\hline & $\mathrm{BB}$ & 6 & 44.60 & 6.29 & \\
\hline \multirow[t]{2}{*}{ Protein (kg) } & $\mathrm{Bb}$ & 21 & 12.72 & 1.47 & $0.381 \mathrm{NS}$ \\
\hline & $\mathrm{BB}$ & 6 & 12.10 & 1.70 & \\
\hline \multirow[t]{2}{*}{ Minerals $(\mathrm{kg})$} & $\mathrm{Bb}$ & 21 & 4.43 & 0.543 & $30.339 \mathrm{NS}$ \\
\hline & $\mathrm{BB}$ & 6 & 4.18 & 0.55 & \\
\hline \multirow[t]{2}{*}{ Body fat mass (kg) } & $\mathrm{Bb}$ & 21 & 36.06 & 8.59 & 0.374 NS \\
\hline & $\mathrm{BB}$ & 6 & 40.40 & 15.49 & \\
\hline \multirow[t]{2}{*}{ Percent body fat (\%) } & $\mathrm{Bb}$ & 21 & 35.76 & 5.18 & $0.189 \mathrm{NS}$ \\
\hline & $\mathrm{BB}$ & 6 & 39.08 & 5.75 & \\
\hline \multirow{2}{*}{$\begin{array}{l}\text { Skeletal muscle mass } \\
(\mathrm{kg})\end{array}$} & $\mathrm{Bb}$ & 21 & 36.36 & 4.43 & 0.383 NS \\
\hline & $\mathrm{BB}$ & 6 & 34.48 & 5.13 & \\
\hline \multirow[t]{2}{*}{ Trunk free fat mass (kg) } & $\mathrm{Bb}$ & 21 & 28.44 & 3.16 & $0.740 \mathrm{NS}$ \\
\hline & $\mathrm{BB}$ & 6 & 27.93 & 3.87 & \\
\hline \multirow[t]{2}{*}{ Visceral fat level } & $\mathrm{Bb}$ & 21 & 15.29 & 3.88 & $0.305 \mathrm{NS}$ \\
\hline & $\mathrm{BB}$ & 6 & 17.33 & 5.35 & \\
\hline
\end{tabular}

statistically significant relationship between $B b$ and $B B$ genotypes in Groups I and II, with the prevalence of BB genotype being higher in the vitamin-D-deficient group $(\mathrm{P}=1.00$ in Fisher's exact test). The frequency of Bb genotype (80\%) among obese subjects is shown in Fig. 2.

We found no statistically significant relationship between the iron profile (iron level, ferritin level, TIBC, and transferrin saturation) and $B s m l$ gene polymorphism, as shown in Table 5 and Fig. $3(\mathrm{P}>0.05)$. However, the relationship between $\mathrm{HbA1c}$ level and $B s m l$ gene polymorphism was statistically significant $(P=0.002)$, with a higher mean value in $\mathrm{Bb}$ genotype carriers than in $\mathrm{BB}$ genotype carriers. This figure shows that the relation between HbA1c and BsmI gene polymorphism was statistically significant with an increase in mean value in $B b$ genotype than $B B$ genotype.

Table 6 and Fig. 4 present the relationship between $\mathrm{CBC}$ parameters and Bsml gene polymorphism. A statistically significant difference was found in eosinophil count between the $B B$ and $B b$ genotype carriers $(\mathrm{P}=0.045)$, with the $B b$ genotype carriers showing a higher mean value than the $B B$ genotype carriers. Other CBC parameters showed no statistically significant relationship with $B s m l$ gene polymorphism $(\mathrm{P}>0.05)$.

\section{Discussion}

Vitamin D deficiency has remained a global problem over the past 25 years. Due to polymorphic VDR expression, an individual may obtain little or no vitamin-D-related advantages even if his/her vitamin D levels are normal. Multiple clinical investigations have linked VDR gene polymorphisms, including FokI, ApaI, TaqI, and BsmI, to obesity and metabolic syndrome. Genetic and immunological investigations have been conducted on obese individuals to explore the mechanisms underlying VDR polymorphism (BsmI) in the etiology of obesity [10].

Regarding the VDR gene polymorphism BsmI, we found that 24 participants had the $B b$ genotype, and six had the $B B$ genotype, indicating that the " $b$ " allele was more prevalent among obese participants.

Vitamin D levels and BsmI gene polymorphism also showed a correlation. In Group I with normal vitamin $D$ levels, all the seven subjects with insufficient vitamin $\mathrm{D}$ levels had the $B b$ genotype (six Bb genotype carriers and one $B B$ genotype carrier), whereas in Group II with deficient vitamin D levels, all the five participants were $B b$ genotype carriers. In contrast, we detected $13 B b$ genotype carriers and $5 B B$ genotype carriers in Group II with low vitamin $\mathrm{D}$ levels. The incidence of $B B$ genotype was higher among vitamin-D-deficient individuals, and $B b$ genotype carriers were more common among obese participants than $B B$ genotype carriers. Nevertheless, the findings were not statistically significant.

In some populations, VDR and its genetic variations are known to influence the risk of obesity. Although the significance of low vitamin D levels in the development of obesity remains uncertain, some studies have shed light on the link between the two conditions. According to Kull et al,, obese people are less exposed to sunlight compared with nonobese adults because of reduced physical activity or clothing patterns that impair cutaneous 
Table 4 Bsml gene polymorphism among male obese students with deficient and nondeficient vitamin D levels

\begin{tabular}{|c|c|c|c|c|c|}
\hline & & & \multicolumn{2}{|l|}{ Vitamin D Level } & \multirow[t]{2}{*}{ Total } \\
\hline & & & Above (20 ng/ml) & Below $(20 \mathrm{ng} / \mathrm{ml})$ & \\
\hline \multirow[t]{4}{*}{ Bsml polymorphism } & $\mathrm{Bb}$ & $\mathrm{N}$ & 10 & 14 & 24 \\
\hline & & $\%$ & $41.7 \%$ & $58.3 \%$ & $100.0 \%$ \\
\hline & $\mathrm{BB}$ & $\mathrm{N}$ & 2 & 4 & 6 \\
\hline & & $\%$ & $33.3 \%$ & $66.7 \%$ & $100.0 \%$ \\
\hline \multirow[t]{2}{*}{ Total } & & $\mathrm{N}$ & 12 & 18 & 30 \\
\hline & & $\%$ & $40.0 \%$ & $60.0 \%$ & $100.0 \%$ \\
\hline Fisher exact test $\mathrm{P}$ value & & $1.00 \mathrm{NS}$ & & & \\
\hline
\end{tabular}

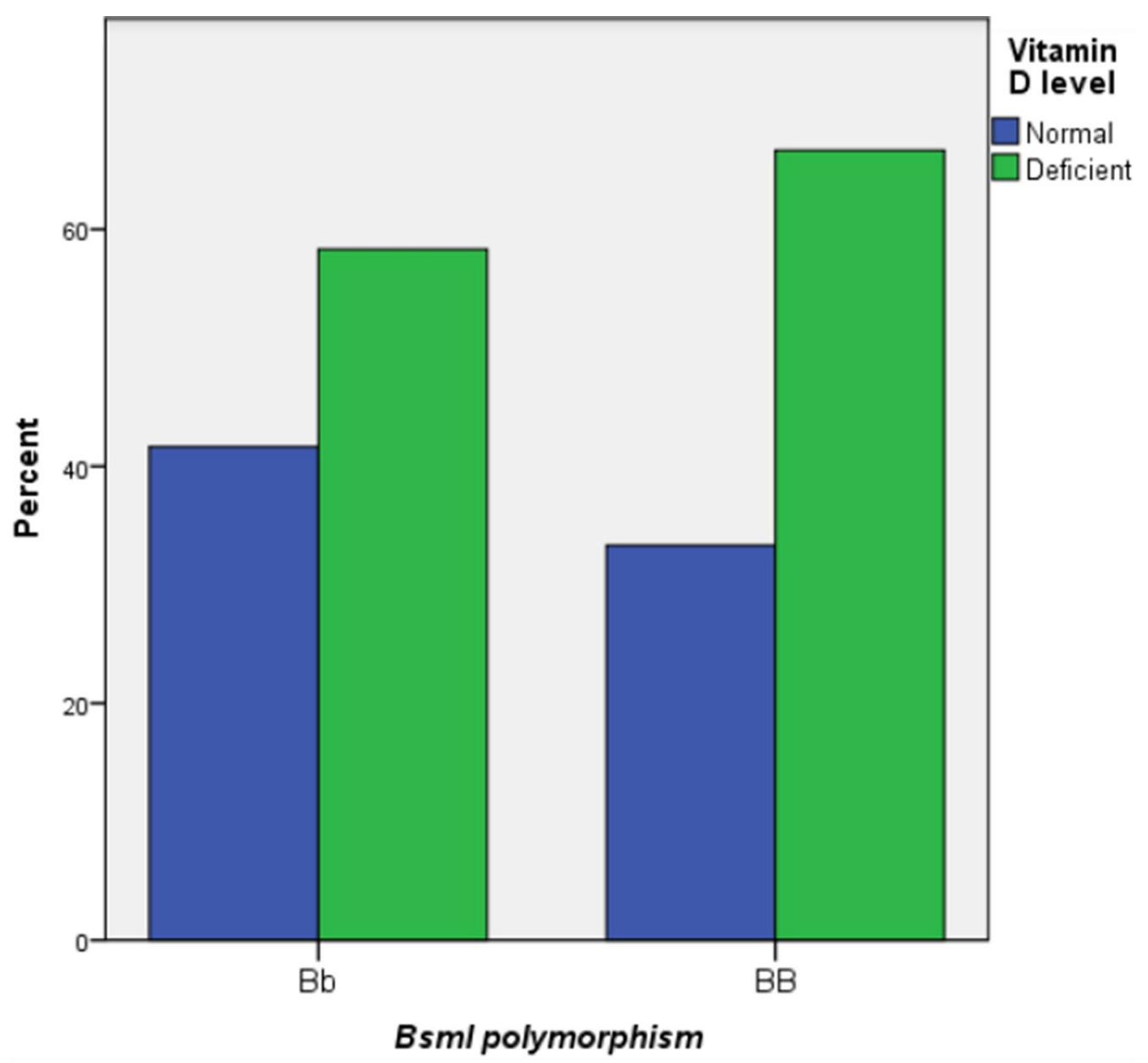

Fig. $1 \mathrm{Bsm} /$ gene polymorphism among male obese students with deficient and nondeficient vitamin D levels

vitamin D production [11]. Another in vitro study demonstrated that deficient vitamin D levels in obese subjects are due to adipose tissue sequestration of this vitamin [9]. Another notion is that due to hepatic steatosis, vitamin $\mathrm{D}$ production by the liver is reduced in obese people. Moreover, higher levels of circulating leptin and interleukin 6, which are largely produced by adipose tissue, may impede vitamin $\mathrm{D}$ production through their receptors [12].

Vitamin D deficiency also causes impaired insulin sensitivity, increased fat mass, and accelerated lipogenesis [13]. 


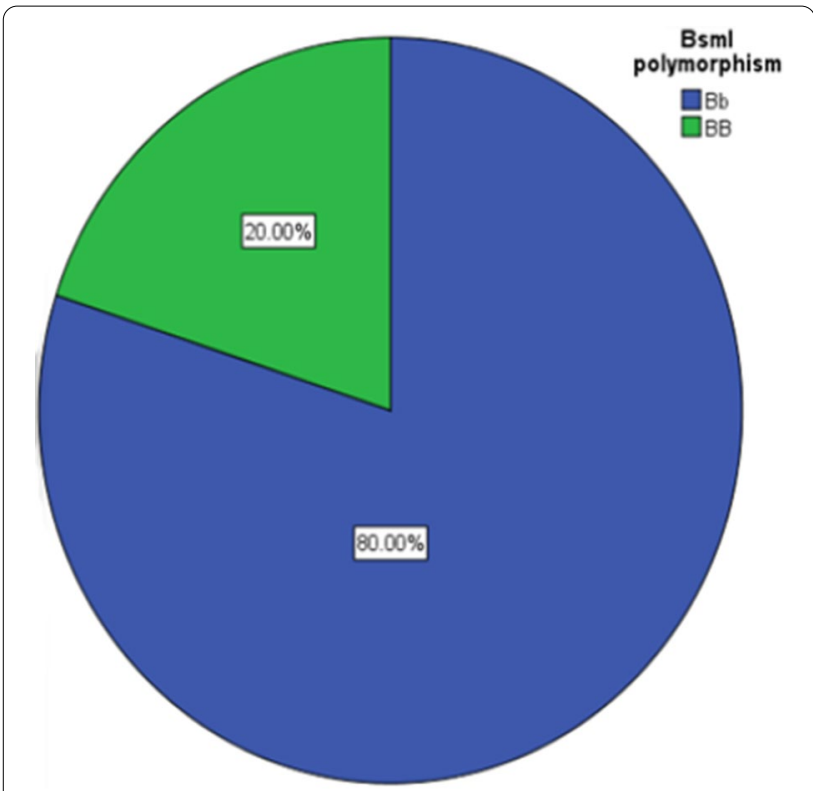

Fig. $2 \mathrm{Bsm} /$ gene polymorphism among obese male students

Table 5 Iron profile and $\mathrm{HbA1C}$ in relation to $\mathrm{Bsml}$ gene polymorphism among obese male medical students

\begin{tabular}{llllll}
\hline & $\begin{array}{l}\text { Bsml } \\
\text { polymorphism }\end{array}$ & N & Mean & SD & P value \\
\hline Fe $(\mu \mathrm{g} / \mathrm{dL})$ & $\mathrm{Bb}$ & 19 & 99.3 & 39.9 & $0.918 \mathrm{NS}$ \\
& $\mathrm{BB}$ & 6 & 97.5 & 31.4 & \\
Total iron binding capac- & $\mathrm{Bb}$ & 19 & 329.9 & 32.4 & $0.493 \mathrm{NS}$ \\
ity (TIBC) $(\mu \mathrm{g} / \mathrm{dL})$ & $\mathrm{BB}$ & 6 & 341.1 & 40.4 & \\
Ferritin $(\mathrm{ng} / \mathrm{mL})$ & $\mathrm{Bb}$ & 18 & 154.3 & 143.0 & $0.734 \mathrm{NS}$ \\
& $\mathrm{BB}$ & 6 & 176.3 & 104.1 & \\
Transferrin saturation $(\%)$ & $\mathrm{Bb}$ & 19 & 30.1 & 11.1 & $0.889 \mathrm{NS}$ \\
& $\mathrm{BB}$ & 6 & 29.3 & 11.0 & \\
HbA1c (\%) & $\mathrm{Bb}$ & 21 & 5.0 & 0.89 & $\mathbf{0 . 0 0 2} \mathbf{S}$ \\
& $\mathrm{BB}$ & 6 & 4.5 & 0.45 & \\
\hline
\end{tabular}

Human subcutaneous adipose tissue, visceral adipose tissue, and breast adipocytes have been found to express VDR. Vitamin D can both control and be regulated by adipose tissue. Human adipocytes have been shown to exhibit VDR, 25-hydroxyvitamin D 1-hydroxylase genes, and the 24-hydroxylase enzyme [14].

Ruiz-Ojeda et al. reported about relationships with VDR polymorphisms that could be attributed to either a major effect of vitamin $\mathrm{D}$ on adipocyte differentiation and metabolism or an indirect effect via the modulation of insulin secretion [15]. Vitamin D is known to suppress gluconeogenesis, enhance HDL cholesterol levels, improve the adipokine profile, and increase leptin levels in adipose tissue. The active metabolite of vitamin D affects pancreatic beta cells, changing insulin sensitivity and improving the lipid profile. Consequently, insulin receptor expression increases, and insulin sensitivity improves. Vitamin D is required for reducing the risk of type 2 diabetes and altering the adipokine secretion profile [16].

Although we found no statistical significance between VDR gene polymorphism and BMI, waist-hip ratio (WHR), or other InBody bioelectrical impedance parameters in our study concerning the association between VDR gene polymorphism and obesity development, we did observe a prevalence of $\mathrm{Bb}$ genotype carriers among obese male students. Because the BsmI gene is found in the introns of VDR gene, it may have an impact on gene expression, mRNA stability, and protein translation efficiency [17]. Thus, according to Chen et al., SNPs such as the " $b$ " allele in BsmI, which can result in reduced VDR mRNA and protein expressions, may be related to an increased risk of developing obesity [18].

Bagheri et al. found that BsmI polymorphism was not associated with obesity risk in the Iranian population [19]. However, another study showed that the " $b$ " allele of the BsmI marker was more common among obese Saudi Arabians [9].

The effects of VDR polymorphism on body size were also explored, and it was found that the " $b$ " allele in BsmI was linked to obesity in Caucasian women [20].

There was no relationship between vitamin D levels and the InBody bioelectrical impedance characteristics in our study. Other studies on people with vitamin D deficiency and obesity also showed no relationship between vitamin $\mathrm{D}$ levels and visceral fat, which supports our findings [21]. In two clinical trials of obese people, no significant changes were detected in body weight, WHR, or vitamin D levels [22],23.

Our findings support those of Vimaleswaran et al., who found no relationship between VDR, waist circumference, BMI, and other obesity-related parameters. Tworowska-Bardziska et al. also validated this conclusion in their study on a Polish cohort [24]25.

However, our findings were in contrast to the study of Bienertová-Vašků et al. conducted on 882 Central European Caucasian individuals, in which weight, height, BMI, lean body mass, fat mass, body fat, waist and hip circumference, waist-hip ratio, and skinfold thickness were measured, and the VDR BsmI gene polymorphism was investigated, reporting a relationship with waist circumference [26]. The cross-sectional study of Karonova et al. on 697 participants supports our findings. They evaluated the VDR gene polymorphism rs 1544410 (BsmI), serum vitamin D concentration, and anthropometric measurements and reported no significant relationship between the VDR SNP rs1544410 (BsmI), 


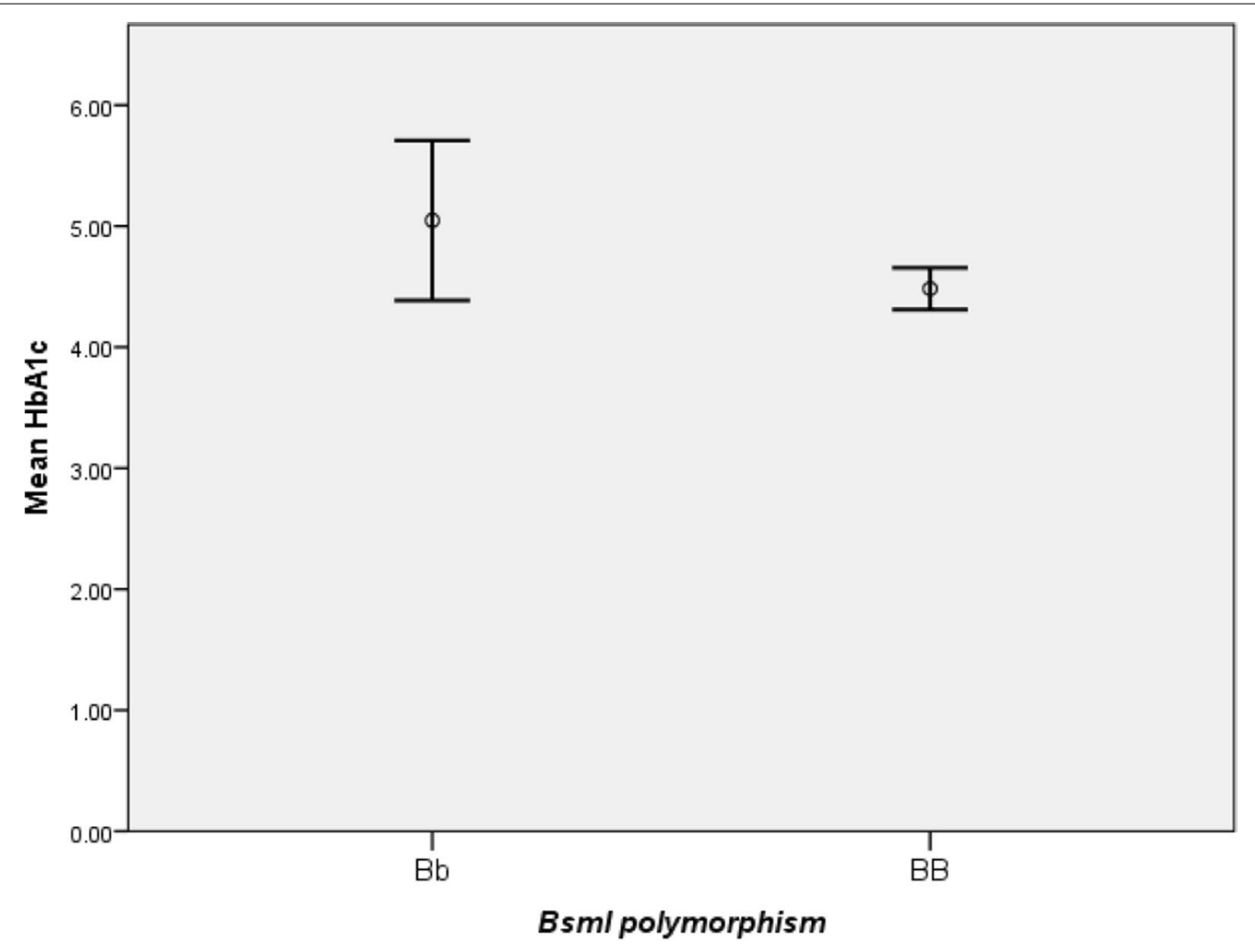

Fig. 3 Relation between Bsm/ polymorphism and $\mathrm{HbA1C}$

Error Bars: +/- $1 \mathrm{SD}$

Table 6 Blood cells profile in relation to Bsml gene polymorphism among obese male medical students

\begin{tabular}{|c|c|c|c|c|c|}
\hline & $\begin{array}{l}\text { Bsml } \\
\text { polymorphism }\end{array}$ & $\mathrm{N}$ & Mean & SD & $P$ value \\
\hline \multirow[t]{2}{*}{ Hemoglobin (Hb) (g/dl) } & $\mathrm{Bb}$ & 21 & 14.6 & 1.0 & 0.474 NS \\
\hline & $\mathrm{BB}$ & 5 & 14.9 & 0.9 & \\
\hline \multirow{2}{*}{$\begin{array}{l}\text { Total leucocytic count } \\
\text { (TLC) } \\
\times 10^{3} \mu \mathrm{L}\end{array}$} & $\mathrm{Bb}$ & 21 & 7.1 & 2.1 & $0.622 \mathrm{NS}$ \\
\hline & BB & 5 & 6.6 & 2.8 & \\
\hline \multirow{2}{*}{$\begin{array}{l}\text { Neutrophils } \\
\times 10^{3} \mu \mathrm{L}\end{array}$} & $\mathrm{Bb}$ & 21 & 4.2 & 1.8 & 0.609 NS \\
\hline & BB & 5 & 3.7 & 1.9 & \\
\hline \multirow{2}{*}{$\begin{array}{l}\text { Lymphocytes } \\
\times 10^{3} \mu \mathrm{L}\end{array}$} & $\mathrm{Bb}$ & 21 & 2.3 & 0.5 & 0.866 NS \\
\hline & BB & 5 & 2.4 & 0.7 & \\
\hline \multirow{2}{*}{$\begin{array}{l}\text { Monocytes } \\
\times 10^{3} \mu \mathrm{L}\end{array}$} & $\mathrm{Bb}$ & 21 & 0.4 & 0.2 & $0.987 \mathrm{NS}$ \\
\hline & BB & 5 & 0.3 & 0.3 & \\
\hline \multirow{2}{*}{$\begin{array}{l}\text { Eosinophils } \\
\times 10^{3} \mu \mathrm{L}\end{array}$} & $\mathrm{Bb}$ & 21 & 0.15 & 0.13 & $0.045 \mathrm{~S}$ \\
\hline & BB & 5 & 0.01 & 0.04 & \\
\hline \multirow[t]{2}{*}{ Basophils $\times 10^{3} \mu \mathrm{L}$} & $\mathrm{Bb}$ & 21 & 0.014 & 0.03 & $0.762 \mathrm{NS}$ \\
\hline & BB & 5 & 0.020 & 0.04 & \\
\hline \multirow[t]{2}{*}{ Platelets $\times 10^{3} \mu \mathrm{L}$} & $\mathrm{Bb}$ & 21 & 292.0 & 52.7 & $0.227 \mathrm{NS}$ \\
\hline & BB & 5 & 253.2 & 58.7 & \\
\hline
\end{tabular}

serum vitamin D concentration, anthropometric characteristics, and metabolic syndrome risk [27].

Zhao et al. conducted a study on Northern Chinese population and observed a strong relationship between the BsmI VDR gene polymorphism and metabolic syndrome, which is in contrast to our findings. They found that the $B B$ genotype and $B$ allele were risk factors for metabolic syndrome. The role of the bb genotype was unknown due to its rarity [28].

Marozik et al. predicted that the level of VDR mRNA was dramatically higher in $B B$ genotype carriers than in $b b$ genotype carriers, which could explain our study finding regarding the predominance of $B B$ genotype with vitamin $D$ deficiency in obese male students. VDR receptor expression was higher among $B B$ genotype carriers, resulting in enhanced vitamin D catabolism. A possible mechanism is that a variation in VDR receptor activation alters vitamin-D-mediated gene expression [29].

Our findings, which were consistent with those of ElHoseiny et al., showed that vitamin D insufficiency was more common among $B B$ genotype carriers $(66.7 \%)$ than among $B b$ and $b b$ genotype carriers (33.3\%) [30]. El-Edel et al. also found that patients with beta thalassemia with 


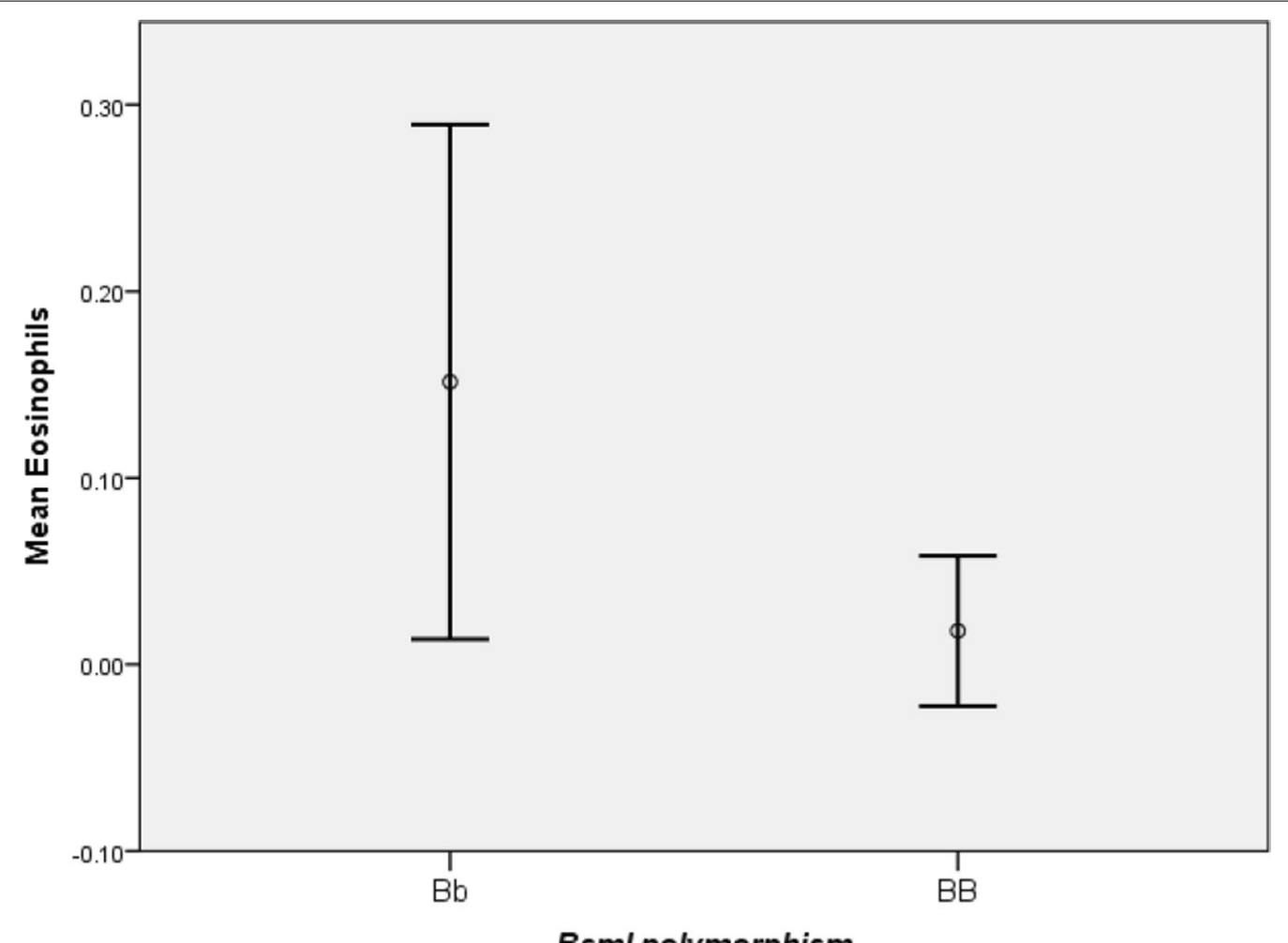

Bsml polymorphism

Fig. 4 Relation between Bsm/ polymorphism and Eosinophil

Error Bars: +/- $1 \mathrm{SD}$

the $B B$ genotype had significantly lower bone mineral density than those with the $b b$ or $B b$ genotype [31].

We suggest that people with VDR genotypes have a wide range of serum vitamin D concentrations, which further suggests that vitamin D supplementation may not be appropriate for everyone. The association between genetic variations and vitamin $\mathrm{D}$ status should also be further investigated.

Vitamin D exerts functions such as antioxidation, free radical scavenging, and neuroprotection. Therefore, a deficiency in this vitamin plays an important role in the initiation and progression of hypertension. The reninangiotensin system, which has been reported to regulate blood pressure through vitamin $\mathrm{D}$, is well known to be at the center of hypertension regulation [32].

Vitamin D acts on VDR, which is found on B cells, T cells, dendritic cells, and macrophages, and possesses immunomodulatory capabilities. VDR-expressing eosinophils have a longer lifespan [33].

In the present study, we detected a statistically significant difference between $\mathrm{BB}$ and $\mathrm{Bb}$ genotype carriers in terms of eosinophil count, with $B b$ genotype carriers having a higher mean value than $B B$ genotype carriers. This finding may have implications for VDR function and, therefore, the role of vitamin D in immunomodulation. Further research is required to understand better about this enigmatic association.

In contrast to the study of De Groot et al., Filho et al. reported that lower serum vitamin D levels were related to an increased blood eosinophil count [34] [35].

We observed a statistically significant relationship between HbA1c levels and BsmI gene polymorphisms and an increase in mean value in $B b$ genotype carriers compared with $B B$ genotype carriers. According to Ezhilarasi et al., BsmI SNPs in the VDR gene are associated with a range of biochemical markers, including BMI, fasting glucose, HbA1c, and lipid profile [36]. The study of Mackawy and Badawi [37] also supports our findings.

The primary strength of our study was the fact that it is a pilot investigation, and moreover, all candidates were of same age and gender, which helps reduce gender disparities in various parameters. This study is also a continuation of a large project attempting to determine the effect of vitamin D and VDR gene polymorphism on obesity and its negative outcomes on various scales. In addition, laboratory tests were conducted by trained specialists, and the individuals provided detailed physical and medical history. 
However, the small sample size may be the most significant limitation in our study. Moreover, we investigated only one VDR SNP, and hence, further research on other VDR gene polymorphisms is necessary to widen our study scope and understand better about the complex relationship between VDR gene polymorphism and obesity.

\section{Conclusions}

The VDR gene polymorphism BsmI and BMI, as well as the various InBody bioelectrical impedance parameters, showed no significant relationship. There was also no significant relationship between BsmI gene polymorphism and vitamin D levels; however, vitamin $D$ deficiency was observed to be more common among $B B$ genotype carriers than among $B b$ genotype carriers, suggesting that the $B B V D R$ genotype is a key cause of vitamin D deficiency. Moreover, we found that obese students have a high incidence of the " $b$ " allele. We also noticed a relationship between BsmI gene polymorphism and HbA1c level and eosinophil count, which requires further investigation.

\section{Abbreviations}

BMI: Body Mass Index; NFQ: Nonfluorescent Quencher; PCR: Polymerase Chain Reaction; SNP: Single Nucleotide Polymorphism; SD: Standard Deviation; VDR: Vitamin D Receptor; WHR: Waist-Hip Ratio.

\section{Acknowledgements}

The authors highly appreciate the support from Clinical Pathology Department, Faculty of Medicine, Ain Shams University, for the outstanding support during the entire experiment.

\section{Authors' contributions}

YK recruited cases, collected samples, contributed to scientific writing, and conducted laboratory procedures. RR was involved in supervision of the research. ME-G contributed to statistical analysis. YZ was involved in supervision of the research. RA-S contributed to scientific writing, editing and revision, and searching references. WA was involved in scientific writing and conducted laboratory procedures. All authors read and approved the final manuscript.

\section{Funding}

This study received no financial support.

\section{Availability of data and materials}

All data and materials are available on request with agreement for publication.

\section{Declarations}

Ethical approval and consent to participants

The protocol was discussed and approved by the ethical scientific committee of Ain Shams University Faculty of Medicine.

\section{Consent for publication}

Written informed consent for publication was obtained from all participants under the Creative Commons Attribution License 4.0

\section{Competing interests}

All the authors declare no competing interests.

\section{Author details}

${ }^{1}$ Department of Clinical Pathology, Faculty of Medicine, Ain Shams University, Ramses Street (Ahmed Lotfy Elsayed Street), Abbassia, Cairo 11566, Egypt.

${ }^{2}$ Department of Public Health and Community Medicine, Faculty of Medicine, Ain Shams University, Cairo, Egypt.

Received: 3 November 2021 Accepted: 24 February 2022 Published online: 08 March 2022

\section{References}

1. Santoro D, Caccamo D, Lucisano S, Buemi M, Sebekova K, Teta D (2015) Interplay of vitamin $D$, erythropoiesis, and the renin-angiotensin system. BioMed Res Int 2015:145828. https://doi.org/10.1155/2015/145828

2. Cobayashi F, Lourenço B, Cardoso M (2015) 25-Hydroxyvitamin D3 levels, Bsml polymorphism and insulin resistance in Brazilian Amazonian children. Int J Mol Sci 16(6):12531. https://doi.org/10.3390/ijms160612531

3. Gacem S, Shahwan M (2019) Vitamin D and obesity, vitamin. IntechOpen. https://doi.org/10.5772/intechopen.90181

4. Karonova T, Grineva E, Belyaeva O, Bystrova A, Jude EB, Andreeva A, Pludowski P (2018) Relationship between vitamin D status and vitamin $D$ receptor gene polymorphisms with markers of metabolic syndrome among adults. Front Endocrinol 9:448

5. Zhu J, Bing C, Wilding JPH (2018) Vitamin D receptor ligands attenuate the inflammatory profile of $\mathrm{L}-1 \beta$-stimulated human white preadipocytes via modulating the NF-KB and unfolded protein response pathways. Biochem Biophys Res Commun 2018(503):1049-1056

6. Pike JW, Meyer MB, Benkusky NA, Lee SM, St John H, Carlson A (2016) Genomic determinants of vitamin D-regulated gene expression. Vitam Horm 100:21-44. https://doi.org/10.1016/bs.vh.2015.10.011

7. Wysoczańska A, Ślęzak I, Hetman M, Barg E (2018) The impact of VDR gene polymorphisms on obesity, metabolic changes, bone mass disorders and neoplastic processes. J Res 24(2):96-105

8. Mangin M, Sinha R, Fincher K (2014) Inflammation and vitamin D: the infection connection. Inflamm Res 63(10):803-819. https://doi.org/10. 1007/s00011-014-0755-z

9. Al-Hazmi A, Al-Mehmadi M, Al-Bogami S, Shami A, Al-Askary A, Alomery A, Alharb F (2017) Vitamin D receptor gene polymorphisms as a risk factor for obesity in Saudi men. Electron Phys 9(10):5427

10. Sakharkar P, Deb S, Vu D (2017) Vitamin D receptor (VDR) gene polymorphism: implications on non-bone diseases. J Basic Clin Pharm 8:S06-S10

11. Kull M, Kallikorm R, Lember M (2009) Body mass index determines sunbathing habits: implications on vitamin D levels. Intern Med J 39(4):256258. https://doi.org/10.1111/j.1445-5994.2009.01900

12. Cipriani C, Pepe J, Piemonte S, Colangelo L, Cilli M, Minisola S (2014) Vitamin D and its relationship with obesity and muscle. Int J Endocrinol Article ID 841248. https://doi.org/10.1155/2014/841248

13. Zakharova I, Klimov L, Kuryaninova V, Nikitina I, Malyavskaya S, Dolbnya S, Lebedev A (2019) Vitamin D insufficiency in overweight and obese children and adolescents. Front Endocrinol 10:103

14. Earthman C, Beckman L, Masodkar K, Sibley S (2012) The link between obesity and low circulating 25-hydroxyvitamin D concentrations. Int J Obes (Lond) 36(3):387-396

15. Ruiz-Ojeda F, Anguita-Ruiz A, Leis R, Aguilera C (2018) Genetic factors and molecular mechanisms of vitamin D and obesity relationship. Ann Nutr Metab 73:89-99. https://doi.org/10.1159/000490669

16. El-Hajj G (2012) Can the sunshine vitamin melt the fat metabolism? J Metabol 61:603-610

17. Valdivielso J, Fernandez E (2006) Vitamin D receptor polymorphisms and diseases. Clin Chim Acta Int J Clin 371:1-2

18. Chen X, Wang W, Wang Y, Han X, Gao L (2019) Vitamin D receptor polymorphisms associated with susceptibility to obesity: a meta-analysis. Med Sci Monit 25:8297-8305

19. Bagheri M, Bahadori F, Gheibi S (2017) Vitamin D receptor gene haplotype and late-onset obesity in Iranian Azeri Turkish women. Maedica (Bucur) 12(2):81-86

20. Faghfouri A, Faghfur E, Maleki V, Payahoo L, Balmoral A, Bishak Y (2020) A comprehensive insight into the potential roles of VDR gene 
polymorphism in obesity: a systematic review. Arch Physiol Biochem. https://doi.org/10.1080/13813455.2020.1788097

21. Abootorabi M, Ayremlou P, Behroozi-Lak T, Nourisaeidlou S (2017) The effect of vitamin $D$ supplementation on insulin resistance, visceral fat and adiponectin in vitamin D deficient women with polycystic ovary syndrome: a randomized placebo-controlled trial. Gynecol Endocrinol 34(6):489-494. https://doi.org/10.1080/09513590.2017.1418311

22. Batista A, Ambrosim T, Nascimento R (2016) (2016): Hypovitaminosis D is associated with visceral adiposity, high levels of low-density lipoprotein and triglycerides in alternating shift workers. J Endocrinol Metab 6:80-89

23. Muscogiuri G, Sorice G, Prioletta A (2010) (2010): 25-Hydroxyvitamin D concentration correlates with insulin-sensitivity and BMI in obesity. Obesity (Silver Spring) 18:1906-1910

24. Vimaleswaran K, Cavadino A, Berry D, Whittaker J, Power C, Järvelin M (2013) Genetic association analysis of vitamin D pathway with obesity traits. Int J Obes 37(10):1399-1406

25. Tworowska-Bardzinska U, Lwow F, Kubicka E, Łaczmanski Ł, Jedzrzejuk D, Dunajska K (2008) The vitamin D receptor gene Bsml polymorphism is not associated with anthropometric and biochemical parameters describing metabolic syndrome in postmenopausal women. Gynecol Endocrinol 24:514-551. https://doi.org/10.1080/09513590802302985

26. Bienertová-Vašků J, Zlámal F, Pohořalá A, Mikes O, Goldbergová-Pávková M, Novák J, Šplíchal Z, Pikhart H (2017) Allelic variants in vitamin D receptor gene are associated with adiposity measures in the central-European population. BMC Med Genet Vol 18, Article number: 90

27. Karonova T, Grineva E, Belyaeva O, Bystrova A, Jude E, Andreeva A, Kostareva S, Pludowski P (2018) Relationship between vitamin D status and vitamin $\mathrm{d}$ receptor gene polymorphisms with markers of metabolic syndrome among adults. https://doi.org/10.3389/fendo.2018.00448

28. Zhao Y, Liao S, He J, Jin Y, Fu H, Chen X (2014) (2014): Association of vitamin $D$ receptor gene polymorphisms with metabolic syndrome: a casecontrol design of population-based cross-sectional study in North China. Lipids Health Dis 13:129. https://doi.org/10.1186/1476-511X-13-129

29. Marozik P, Rudenka A, Kobets K, Rudenka E (2021) Vitamin D status, bone mineral density, and VDR gene polymorphism in a cohort of belarusian postmenopausal women. Nutrients 13:837. https://doi.org/10.3390/ nu13030837

30. El-Hoseiny S, Morgan D, Rabie A, Bishay S (2016) Vitamin D receptor (VDR) gene polymorphisms (Fokl, Bsml) and their relation to vitamin D status in pediatrics beta thalassemia major. Indian J Hematol Blood Transf 32(2):228-238. https://doi.org/10.1007/s12288-015-0552-z

31. El-Edel R, Ghonaim M, Abo-Salem O, El-Nemr F (2010) Bone mineral density and vitamin $\mathrm{D}$ receptor polymorphism in beta-thalassemia major. Pak J Pharm Sci 23(1):89-96

32. Li Z, Zhu Y, Ding N (2019) The association between vitamin D receptor gene polymorphism and susceptibility to hypertension: a meta-analysis. Eur Rev Med Pharmacol Sci 23:9066-9074

33. Ethier C, Yu Y, Cameron L, Lacy P, Davoine F (2016) Calcitriol 293 reduces eosinophil necrosis which leads to the diminished 294 releases of cytotoxic granules. Int Arch Allergy Immunol 171:119-129

34. De Groot J, Van Roon E, Storm H, Veeger N, Zwinderman A, Hiemstra P (2015) Vitamin D reduces eosinophilic airway 283 inflammation in nonatopic asthma. J Allergy Clin Immunol 135:670-675

35. Filho S, De Andrade A, Ribeiro F, Alves P, Simonini V (2018) Impact of vitamin D deficiency on increased blood eosinophil counts. Hematol Oncol Stem Cell Ther 11(1):25-29

36. Ezhilarasi K, Dhamodharan U, Vijay V (2018) BSMI single nucleotide polymorphism in vitamin $\mathrm{D}$ receptor gene is associated with decreased circulatory levels of serum 25 -hydroxyvitamin $\mathrm{D}$ among micro and macrovascular complications of type 2 diabetes mellitus. Int J Biol Macromol 116:346-353

37. Mackawy A, Badawi M (2014) Association of vitamin D and vitamin D receptor gene polymorphisms with chronic inflammation, insulin resistance and metabolic syndrome components in type 2 diabetic Egyptian patients. Meta gene 2(2014):540-556

\section{Publisher's Note}

Springer Nature remains neutral with regard to jurisdictional claims in published maps and institutional affiliations.

\section{Submit your manuscript to a SpringerOpen ${ }^{\circ}$ journal and benefit from:}

- Convenient online submission

- Rigorous peer review

- Open access: articles freely available online

- High visibility within the field

- Retaining the copyright to your article

Submit your next manuscript at $\boldsymbol{\nabla}$ springeropen.com 